\title{
CHRISTELIKE HOËR ONDERWYS EN DIE TEOLOGIE.
}

\section{DIE BEGRIP „TEOLOGIE."}

Die woord „teologie" is veelsinnig en kan o.m. beteken: 1. Die kennis wat God van Homself het. 2. Die leerstuk in die Dogmatiek wat spesiaal oor die wese van God handel, of ook: 3. Die kennis van God wat geput word uit die openbaring, d.i. soos mense God ken. Dit is veral in hierdie laaste sin dat ons teenswoordig van teologie spreek, en dan word daaronder 'n hele sisteem van vakke verstaan, wat hul saambindingspunt daarin vind dat dit in almal ten slotte gaan om „die kennis van God." Die idee van hierdie sisteem van vakke word beter weergegee deur die benaming „Godgeleerdheid." Hierdie woord bring duidelik aan die lig wat ook in die Griekse „theologein" opgesluit lê. Dit kan naamlik, wat die afleiding betref, sowel „spreek oor God” as „nadink oor God" beteken. Die „spreek oor God" sal wel meestal eerste voorkom, omdat 'n mens al oor die Almagtige kan spreek, sonder dat juis oor sy wese en deugde nagedink en nagevors is. Vanself ontstaan egter die behoefte om ,te peins oor God," en hierin lê die wese van die saak. Die teologie het met God te doen. lemand wat hierdie sisteem van vakke beoefen, betree heilige grond en moet sy skoene uittrek. Met reg word dan ook gespreek van "heilige Godgeleerdheid."

Die teologie is nie ,godsdienswetenskap" wat die verskillende godsdienste van die werreld tot voorwerp van studie het nie. Ook nie ,die Christendom" of "die religieuse ervaring van die gemeente" nie. Al hierdie omskrywinge vloei daaruit voort dat vir die teologie 'n plekkie aan die universiteit gesoek is. Waar al die ander vakke in een of ander verband met die mens staan, moes ook vir die teologie een of ander uiting van die menslike siel tot voorwerp gemaak word.

Al die uitinge van die siel van die mens bly egter menslik en kan ons geen Godgeleerdheid bied nic. Op naturalistiese standpunt is daar vir die teologie dan ook geen plek nie.

Van Gereformeerde kant is egter altyd volgehou dat die teologie geen bedelaar is om 'n plekkie in die organisme van die wetenskap nie, maar dat die noodsaaklikheid daarvan vanself voortvloei uit die verhouding van die mens tot God. Soos die mens nadink oor die wondere van God in die skepping en onderhouding van alle dinge, is daar ook behoefte om die gedagtes besig te hou met die Skepper van alle dinge.

Elke mens bestaan uit liggaam en siel, waaruit vanself die noodsaaklikheid voortvloui respekticwelik van die fakulteit van geneeskunde 
(mediese fakulteit) en die fakulteit vir die geesteswetenskappe (deur Kuyper die „filologiese fakulteit” genoem). Verder ontwaar die mens teenoor hom die wonderryke natuur, sodat daar behoefte is aan navorsing van die stoflike skepping van God in die naiuurwetenskaplike fakulteit. Maar elkeen vind homself ook lid van 'n menslike gemeenskap, waarvan die onderlinge verhoudinge gereël moet word. In die sisteem van die wetenskappe moet derhalwe 'n belangrike plek vir die fakulteit van die regswetenskappe ingeruim word.

Vir diegene wat op bloot naturalistiese of ateistiese standpunt staan, sou hiermee die universiteit kompleet wees. Immers, die godsdienstige ervarings of uitings van die mens sou heel goed pas in die kader van die geesteswetenskappe. Al gee dit weer wat die mens aangaande godsdienstige sake ervaar en dink, dit bly tog menslik. Van teologie en 'n teologiese fakulteit kan in strikte sin alleen sprake wees aan 'n Universiteit wat bely dat dit in God glo en in sy Lig die lig sien.

Al na gelang van die oortuiging van die beoefenaar, sal dan van Joodse teologie Mohammedaanse teologie ens. gespreek kan word. Vir wie die absoluutheid van die Christendom bely. bestaan daar egter net een teologie wat die naam wesenlik verdien en dit is die Christelike teologie. Geen Christelike universiteit is kompleet sonder sy "teologiese fakulteit," waarin die ,heilige godgcleerdheid" beoefen word nie.

Maar is dit dan nie genoeg dat elke gelowige kinderlik aanvaar wat God van Homself geopenbaar het nie? Is dit nie veel beter nie om in eenvoudigheid van hart te bely: "God is groot en onbegryplik vir ons"? Waarom dan ook hier die denkarbeid van die mens tot die uiterste inspan? Is dit nie veel beter on die Christelike geloof ait te lewe nie?

As die openbaring van God alleen bestaan het in mededeling van lewe en as godsdiens nie meer omvat het as stemminge van die gemoed nie, was daar vir die teologie geen plek nie. Maar-soos dr. Bavinck dit uitdruk-die openbaring is 'n sisteem van woorde en dade van God, 'n ganse wêreld van gedagtes; dit het sy middelpunt in die vleeswording van die Logos. En godsdiens is nie net gevoel en aandoening nie, dit is ook geloof, 'n bewuste lewe, 'n diens van God met hoof en hart albei.

Waar die kinderlike geloof tevrede is met die dat wil die teologiese denkarbeid sover moontlik deurdring tot die waarom en die hoe. Net so min as op die ander lewensgebiede kan die denkarbeid hier op nonaktiwiteit gestel word. Waar die mens na die Beeld van God geskape is. kan hy nie anders nie as om deur te dring tot die ware kennis.

Hieruit volg vanself dat die beoefening van die teologie nie in die eerste plek daar is om die kerk van leraars te voorsien of om die waarheid 
teen die dwaalleringe te verdedig nie. Dit het 'n doel in homself-ook afgesien van die praktiese doeleindes. Daarsonder is geen sisteem van wetenskap kompleet nie.

Die Teologie wil God ken, en daarmee streef dit tegelykertyd na die bereiking van die hoogste doel van die menslike lewe. Calvyn begin sy Kategismus met die vraag: Wat is die hoogste doel van die mens se lewe? En die antwoord is: om God te ken! Die teologie strek na sy idee oor die grense van die teenswoordige tot in die ewigheid. Die beocfenaar daarvan is homself volkome bewus van die reusagtigheid van sy taak, en hy weet dat hy ook in hierdie opsig maar "ten dele" sal ken. Dit bly hier maar-soos die ou vaders dit uitgedruk het-theologia viatorum, Godskennis van die reisigers (na die vaderland), 'n sien deur 'n spieël in 'n raaisel. In die verskiet lê die theologia patriae, die teologie van die vaderland, die sien van aangesig tot aangesig. En selfs dan bly dit pro mensura humane, na menslike maatstaf. Alleen God ken die dieptes van sy eie wese.

In die teenswoordige bedeling verg die teologie moeisame arbeid. In die eerste plek omdat die terrein so ontsaglik uitgebreid is. Die teoloog ondersoek naamlik nie slegs wat op die wese van God betrekking het nie, maar ook sy eienskappe en werkinge in sover dit 'n bydrae lewer in die kennis van God; dit het selfs met die mens te doen in sover hy na die Beeld van God geskape is: Vandaar die geweldige aantal vakke.

In die tweede plek het die teologie dit met ander wetenskappe gemeen dat die sonde as 't ware 'n deksel op die verstand plaas, en waar dit reeds vir die onsondige mens vergun is om maar die omtrekke van Gods wese te bemerk, hoeveel te meer vir die verduisterde verstand?

Eindelik moet nog vermeld word dat die Woord van God geskrywe is in tale wat vandag as dooie tale gekenmerk word, ver verwyder van die tale wat ons ken. Maar genoeg om ons te laat begryp dat ook die teoloog slegs ,in die sweet van sy aanskyn" op sy weg vooruitgang maak

\section{DIE UNIEKE AARD VAN DIE TEOLOGIE.}

In drie belangrike opsigte verskil die Christelike teologie van alle ander wetenskappe.

a. In die verhouding tot die objek van die studie.

By al die ander wetenskappe stel die ondersoeker hom in seker sin bo die voorwerp van sy studie. Om aan die natuur sy geheim te ontworstel, moet die natuurwetenskaplike dit tot 'n mate beheers. Ook hy sal maar altyd weer voor die feit te staan kom dat hy soms sy magteloosheid moet bely wanneer die natuur spot met al sy poginge on tot die wese van 
die dinge deur te dring. Maar, sal hy ooit enige kennis opdoen, dan hang dit tog van sy poginge af. Hy moet die natuur beheers kragtens die koningskap van die mens.

Teenoor God is ons as mense egter absoluut afhanklik. Reeds by 'n ander mens is dit so dat dit uiters moeilik is om tot die dieper roersele van sy siel deur te dring. Maar hier is tog nog enige verwantskap. Ek kan van 'n mens meer te wete kom as van 'n dier, omdat ek self mens is. God, die Almagtige, is egter van alle mense, ja van alle kreature onderskeie. As God Homself nie genadiglik openbaar nie, is daar verder niks te spreek of na te dink nie. Al wat die wetenskap dan kan doen, is om hom besig te hou met denkbeelde oor God. Met ander woorde: in die teologie kan die ondersoeker hom nie bo sy voorwerp van ondersoek stel nie. Presies die omgekeerde gebeur hier: die objek van die ondersoek staan bo die ondersoeker.

b. In die subjek van die studie.

Die skeiding word hier teweeggebring deur die wedergeboorte. In die algemeen kan dieselfde gesê word van die verskil tussen die Christelike en die nie-Christelike wetenskap. Die ondersoeker wat 'n Skrifgelowige is, en diegene wat ' $n$ ongelowige is, sal totaal heterogene produkte voortbring. Hoe hoër egter die voorwerp van ondersoek staan, hoe wyer sal die kloof word, en vanselfsprekend by die teologie die allerwydste. Die onwedergeborene sal met 'n totaal verskillende "feologie" te voorskyn kom. Hy reken immers nie met sonde, met vervreemding van God, 'n vervloekte aarde en 'n verduisterde verstand nie. Ja. op hierdie standpunt is dit problematies of God wel bestaan. Die Christelike teologie verskil wat sy subjek betref dus hemelsbreed van alle ander wetenskappe.

c. In die metode.

By die gewone wetenskappe speel waarneming, spekulatiewe denke en intüsie elk ' $n$ rol. Wie egter in die teologie op die waarneming wil staat maak, kan niks anders as religieuse verskynsels opmerk nie, en dan is hy nog geen teoloog nie. God die Here kan nie deur menslike sintuie waargeneem word nie. Ook die spekulatiewe denke is absoluut onbevoeg om God te vind, en dieselfde geld van die intuïsie. Reeds is vasgestel dat God Homself aan ons moet openbaar, sal ons enige kennis van sy wese ontvang. Hierdie openbaring vind die teoloog in die Heilige Skrif. Ook natuur en geskiedenis is soos 'n boek met letters wat ons die onsienlike dinge van God laat ken, maar as ons die Skrif nie besit het nie, sou hierdie letters onleesbaar gewees het.

Die teologie as wetenskap kan nooit enige nuwe kennis aangaande God bybring nie. Die ander wetenskappe kan deur die verskillende mid- 
dele van waarneming, denke en intuisie altyd meer materiaal vergader. Die godgeleerdheid kan slegs die reeds geopenbaarde beter assimileer en deurdink. Maar hier le dan ook 'n reusagtige taak. Die Skrif is nie 'n wetboek waarin vir elke saak 'n aantal tekste gereed lê nie. Dit kom as 'n stuk lewe, as 'n magtige drama wat deur duisende jare heen afgespeel is. Dit is 'n goudmyn waaruit die kosbare metaal deur eeue van inspanning gehaal word. Elke jaar, elke ecu word die insig van die kerk dieper - mede deur die arbeid van die teologie.

In dic teologie speel waarneming, spekulasie en intuïsie geen rol nie, behalwe in sover dit hulpdiens kan verrig vir die verklaring van die Skrif. Hier geld as onontbeerlike vereiste daardie sesde sintuig-as ons dit so mag noem-die geloof. Dit is dan ook opmerklik dat die teologie in die geskiedenis steeds gebloei het, wanneer die geloofslewe in die kerk op hoogwatermerk gestaan het. Treffend sê dr. Kuyper: „Alleen in tye waarin teoloë aangehou het in die gebed en in die gebed die gemeenskap van die Heilige Gees gesoek het, het die teologie gebloei; waar die sug na geleerdheid ontstaan het, verslap die gebed, verloor die boom van die tcologie sy blare en gaan sy winterslaap tegemoet."

\section{KERK EN TEOLOGIE.}

Die kerk is van die teologie nie afhanklik nie. Reeds lang voordat 'n teologiese wetenskap opgekom het, was in die kerk al 'n warm geloofslewe. Die teologie as wetenskap kom dan ook nie uit die geïnstitueerde kerk voort nie, om die eenvoudige rede dat die kerk as sodanig geen wetenskap beoefen nie. Wel bloei die godgeleerdheid op uit die moederaarde van die Christenheid, van die kerk as organisme. Hierde feit kan selfs so sterk gestel word dat die teologiese wetenskap alleen in die kerk van Christus kan bestaan. Buite die kerk as liggaam van Christus word immers geen wedergeboorte gevind nie.

Hierin lê dan ook die verband tussen teologie en kerk, selfs die geinstitueerde kerk. Die Heilige Skrif waaruit die kerk gebore is, is ook die principium van die teologie. Die kerk gee in sy belydenisskrifte die verwerkte goud, terwyl die teologie vir homself ook hierdie ideaal stel. Dic teoloog sai dus met groot eerbied teenoor die belydenisskrifte van die kerk staan. Hierin vind hy dokumente waarvan die inhoud spruit uit dié warm geloofslewe van die kerk, dikwels met bloed beseël. Hier word gevind produkte van die leiding van die Gees.

Die teoloog gaan derhalwe uit van die belydenis van die kerk; in die geval van die P.U.K. vanselfsprekend van die Formuliere van enigheid. Op sy beurt gaan hy nou hierdie belydenis tocts aan die Heilige Skrif en 
as dit blyk dat daar enige botsing is, word dit ter kennis van dic kerk gebring. 1s die kerk oortuig dat die belydenis in ooreenstemming met die Skrif gebring moet word, dan geskied dit by sinodale besluit.

So ontstaan 'n heerlike wisselwerking tussen kerk en teologie. Op die groot kerkvergaderinge was dit dan ook gewoonlik teoloë van naam wat leiding gegee het by die totstandkoming van die kardinale leerstukke. Dink aan Athanasius, Augustinus, Calvyn, Gomarus e.a. Ons laat dr. Kuyper weer spreek: „Daar is geen enkele geestelike pêrel in die belydenis van die kerk wat dit aan die teologie as sodanig dank nie, ondat dit al die pêrels uit die diepte van die geestelike lewe na bo gebring het. Tog kan dit nie betwis word nie dat dit die kerk nie sou geluk het om die pêrels in sy belydenis tot so'n heerlike snoer aaneen te ryg nie, as die lig van die teologie hierdie geestelike arbeid nie beskyn het nie."

Sal die teologiese fakulteit van die P.U.K. vir C.H.O. ook in die toekoms van betekenis bly, dan mag dit die band met die kerk nooit laat verslap nie.

\section{DIE VRYHEID VAN DIE TEOLOGIESE WETENSKAP.}

Hierdie band met die kerk is geen beletsel vir die vryheid van die teologie nie. Die godgeleerdheid is ewe vry en ewe afhanklik as enige ander wetenskap. Almal is naamlik net gebonde deur die voorwerp van hulle ondersoek. Die teologie is gebonde deur die geopenbaarde Godskennis-dit is deur die Skrif en deur geen menslike bepaling nie.

Die vryheid van die teoloog bestaan hierin dat hy homself altyd weer op die Skrif mag beroep. As hy oortuig is dat die belydenis van sy kerk strydig is met die Woord, is hy verplig om sy kerk te probeer oortuig. Slaag hy nie, is hy verplig om sy amp neer te lê, by gebreke waarvan die kerk deur sy sinode hom daarvan sal onthef. $\mathrm{Hy}$ is dan vry om nog steeds sy standpunt te verdedig, al is dit dan in 'n ander kerklike verband. Nooit mag hy sy gewete geweld aandoen deur te verklaar dat iets swart is, hoewel hy dit as wit sien nie. Dit is wel hard om amp en posisie prys te gee, maar wat beteken hierdie opoffering in vergelyking met die offers wat die martelare vir hulle oortuiging gebring het?

\section{DIE TEOLOGIE EN DIE ANDER CHRISTELIKE WETENSKAPPE.}

Deur die genadige beskikking van God is die P.U.K. in die bevoorregte posisie dat dit 'n komplete teologiese fakulteit besit wat die hoogste grade kan toeken. Die belangstelling vir die hoër studie word dan ook steeds groter, en as die seën van die Here ook in die tockoms nog op die 
fakulteit rus, kan die teologiese arbeid van die P.U.K. nog veel beteken vir die uitbou van 'n eie Afrikaanse Calvinistiese teologie.

Terdeë word deur die ander fakulteite besef dat 'n gesonde verhouding teenoor die teologie moet bestaan. Getuie hiervan is die geloofsleerlesse wat jaar na jaar deur 'n professor van dic teologiese fakulteit gegee en met toenemende belangstelling sowel deur studente as deur lede van die personeel gevolg word. Ook die stafklub sorg dat moeilike vraagstukke steeds van teologiese kant belig word.

As die gesonde harmonie daar is, kan dit nie anders nie of die wisselwerking moet sowel die teologie as die ander wetenskappe ten goede kom. As die dierkunde en die sielkunde bv. op suiwer empiriese gronde die wesensverskil van mens en dier vasstel, het hierdie resultaat vanselfsprekend sy betekenis vir die verklaring van die skepping van die mens na die Beeld van God. So kan meer voorbeelde genoem word.

Mag die teologiese fakulteit van die P.U.K. dan sy deel daartoe bydra dat die Christelike wetenskap as geheel sy roeping vervul deur in die wêreld te verbrei die "polupoikilê sophia"-die „menigvuldige wysheid" van God!

Potchefstroom.

S. DU TOIT. 